\title{
Six random specimens of daytime casual urine on different days are sufficient to estimate daily sodium/potassium ratio in comparison to 7-day 24-h urine collections
}

\author{
Toshiyuki Iwahori ${ }^{1,2}$, Hirotsugu Ueshima ${ }^{2,3}$, Naoko Miyagawa ${ }^{2}$, Naoto Ohgami ${ }^{4}$, Hideyuki Yamashita ${ }^{4}$, \\ Takayoshi Ohkubo ${ }^{5}$, Yoshitaka Murakami ${ }^{6}$, Toshikazu Shiga ${ }^{1}$ and Katsuyuki Miura ${ }^{2,3}$
}

The objective of this study was to determine the optimal number and type of casual (spot) urine specimens required to estimate an individual's urinary sodium/potassium ( $\mathrm{Na} / \mathrm{K}$ ) ratio. A total of 48 participants, 25 men and 23 women, aged between 25 and 59 years, was recruited from healthy volunteers. The $\mathrm{Na} / \mathrm{K}$ ratio in each casual urine and 7-day 24-h urine sample was measured. Correlation analysis and the quality of agreement by the Bland and Altman method between casual urine and 24-h urine were analyzed. The mean $\mathrm{Na} / \mathrm{K}$ ratio of 7-day 24-h urine was 4.3 . The mean $\mathrm{Na} / \mathrm{K}$ ratio of six random specimens of daytime (collected between 09 and 17 hours) casual urine correlated most strongly with the $\mathrm{Na} / \mathrm{K}$ ratio of 7-day 24-h urine $(r=0.87)$. The bias for the mean $\mathrm{Na} / \mathrm{K}$ ratio between 7-day 24-h urine and daytime casual urine was almost negligible (0.03), and the quality of agreement for the mean of the six random, daytime casual urine specimens on different days was similar to that of the 2-day 24-h urine samples for estimating 7-day 24-h values. Our findings show that the mean $\mathrm{Na} / \mathrm{K}$ ratio of six random daytime casual urine specimens on different days was a good substitute for the 2-day 24-h urine $\mathrm{Na} / \mathrm{K}$ ratio.

Hypertension Research (2014) 37, 765-771; doi:10.1038/hr.2014.76; published online 10 April 2014

Keywords: education of patients; potassium; salt; sodium; urine specimen collection

\section{INTRODUCTION}

Worldwide, dietary salt reduction and increasing dietary potassium are considered to be important for reducing blood pressure not only in hypertensive patients but also in the general population. ${ }^{1}$ Many guidelines for the prevention and treatment of hypertension recommend the general public and/or hypertensive patients to reduce their daily salt intake by 5 or $6 \mathrm{~g}^{2-5}$ Despite the rigorous campaign and recommendations for salt restriction, a fairly large gap exists between the recommended target level and the actual salt intake among populations. ${ }^{6,7}$

For effective improvement in dietary salt and potassium intake in hypertensive patients and the general population, it is important for us to develop a convenient, inexpensive and appropriate monitoring system for daily salt and potassium intake. The gold standard for estimating individual daily salt intake is 24 -h urine collection. ${ }^{8}$ The amount of potassium excreted in 24-h urine does not necessarily reflect absolute potassium intake as well as it does sodium, but it shows good correlation with dietary potassium intake. ${ }^{9-11}$ The World Health Organization also reported that an increase in potassium intake in adults and children decreases blood pressure, ${ }^{12}$ and this finding was also substantiated by the good correlation observed between sodium/potassium $(\mathrm{Na} / \mathrm{K})$ ratio in 24 -h urine and blood pressure in epidemiological studies. ${ }^{13-17}$ However, repeated 24-h urine collections are neither easy nor practical for patients at clinics or individuals at home. Although some methods for estimating daily salt intake by casual (spot) urine have been developed as alternatives to 24 -h urine collection, ${ }^{18-20}$ these methods do not estimate individual salt intake, but rather evaluate the average salt intake in populations. Therefore, a new method is needed for estimating individual salt and potassium intake using casual urine. The accuracy of repeated measurements of casual urine for the estimation of $\mathrm{Na}, \mathrm{K}$ and the $\mathrm{Na} / \mathrm{K}$ ratio has not yet been investigated.

The present study was undertaken to determine the optimal number and type of casual urine specimens required for the suitable

\footnotetext{
${ }^{1}$ Research and Development Department, OMRON HEALTHCARE Co., Ltd., Muko, Japan; ${ }^{2}$ Department of Health Science, Shiga University of Medical Science, Otsu, Japan; ${ }^{3}$ Center for Epidemiologic Research in Asia, Shiga University of Medical Science, Otsu, Japan; ${ }^{4}$ Bio-Information System Development Department, OMRON HEALTHCARE Co., Ltd., Muko, Japan; ${ }^{5}$ Department of Hygiene and Public Health, Teikyo University School of Medicine, Tokyo, Japan and ${ }^{6}$ Department of Medical Statistics, Shiga University of Medical Science, Otsu, Japan

Correspondence: Professor H Ueshima, Department of Health Science, Shiga University of Medical Science, Tsukinowa-cho Seta, Otsu, Shiga 520 2192, Japan. E-mail: hueshima@belle.shiga-med.ac.jp
}

Received 26 August 2013; revised 30 December 2013; accepted 26 January 2014; published online 10 April 2014 
estimation of individual daily $\mathrm{Na} / \mathrm{K}$ ratio using 7 -day 24 -h urine collections as the gold standard.

\section{METHODS}

\section{Participants and measurements}

A total of 48 participants, 25 men and 23 women, aged between 25 and 59 years, was recruited from healthy volunteers living in Osaka and its surrounding areas and from workers employed at a health-care products company in Kyoto, Japan. Menstruating women were not included in the study. Participants were instructed to collect all the urine released and to measure the urine volume with a standardized measuring cup at each voiding for a minimum of 7 consecutive days or from the first 7 days of nonconsecutive urine collections of 8 days or more, unless urine collection was unsuccessful or contaminated by feces. A day of urine collection began at 'wake-up' on day one and ended at 'wake-up' the following morning. Urine samples were transferred into an aliquot tube at each voiding, and all samples were sent to the central laboratory at room temperature every 2 days. Participants were asked to record the volume $(\mathrm{ml})$ of each sample and the time of collection. Moreover, participants completed a questionnaire describing their height, weight, physical activity, past medical history and alcohol consumption. Written informed consent was obtained from all participants. The Ethics Committee of the Omron Healthcare Company approved the study protocol.

At the central laboratory, $\mathrm{Na}$ and $\mathrm{K}$ concentrations $\left(\mathrm{mmoll}^{-1}\right)$ of all urine samples were analyzed using ion-selective electrodes (C-122, C-133, Horiba, Kyoto, Japan). The 24-h urinary $\mathrm{Na}$ and $\mathrm{K}$ excretion (mmol per $24 \mathrm{~h}$ ) was calculated from the sum of urinary excretion at each voiding over one day. For each voiding, urinary $\mathrm{Na}$ and $\mathrm{K}$ excretion was calculated from the $\mathrm{Na}$ and $\mathrm{K}$ concentration and urine volume of each voiding sample. $\mathrm{Na} / \mathrm{K}$ ratio of each casual urine sample was calculated using the $\mathrm{Na}$ and $\mathrm{K}$ concentrations of each casual urine sample, and the $24-\mathrm{h}$ urinary $\mathrm{Na} / \mathrm{K}$ ratio was calculated using the $24-\mathrm{h} \mathrm{Na}$ and $\mathrm{K}$ urinary excretion values obtained. Thus, the analytical values in 24-h urine collection were not based on a single collection with a single urine measurement, but were calculated from the weighted average of a series of casual urine samples taken throughout the day.

The timing of casual urine was defined as follows: (1) first morning urine: first voiding after rising, (2) second morning urine: second voiding after rising, (3) daytime casual urine: specimen randomly selected from urine voided between 09 and 17 hours, (4) random casual urine: urine specimen randomly selected among all urine specimens on a certain day. Only one sample per day was randomly selected as the random casual urine specimen for that day. The mean value of $24-\mathrm{h}$ urinary $\mathrm{Na} / \mathrm{K}$ ratios for 7 days for each participant was used as the gold standard for individual urinary $\mathrm{Na} / \mathrm{K}$ ratio. Body mass index was calculated as weight divided by height squared $\left(\mathrm{kg} \mathrm{m}^{-2}\right)$.

\section{Statistical analysis}

The mean $\mathrm{Na} / \mathrm{K}$ ratio, $\mathrm{Na}$ and $\mathrm{K}$ concentrations in casual urine were calculated for the first day, the first 2 days, the first 3 days, etc., up to 7 successive days after the beginning of urine collection for each participant. The same calculations were performed for the first morning urine, the second morning urine, daytime (09 to 17 hours) casual urine and random casual urine, respectively.

Pearson's correlation coefficients were calculated to examine the correlation between values for casual urine and mean values for 24-h urines over 7 days as the gold standard. For example, correlation coefficients were calculated for the first morning urine $\mathrm{Na} / \mathrm{K}$ ratios (value of the first day, the mean of the first 2 days, the mean of the first 3 days, etc., and the mean of all 7 days) and the mean 7-day 24-h urine $\mathrm{Na} / \mathrm{K}$ ratio. The same calculation was also performed for the second morning urine, daytime (09 to 17 hours) casual urine and random casual urine. Random casual urine samples were also selected on each day. Correlations between the $\mathrm{Na}$ and $\mathrm{K}$ concentration of casual urine and the mean 7-day 24-h Na and K excretion were also calculated.

The agreement between 7 -day $24-\mathrm{h}$ urine $\mathrm{Na} / \mathrm{K}$ ratio and the random sampling method for casual urine $\mathrm{Na} / \mathrm{K}$ ratio was examined using the method proposed by Bland and Altman. ${ }^{21}$ The 'agreement' defined by the Bland-
Altman method between the 7-day 24-h urine method and the daytime casual urine method was also compared with the agreement between 7-day 24-h urine $\mathrm{Na} / \mathrm{K}$ ratios and multiple $24-\mathrm{h}$ urine collections from several days.

In sub-analyses, the analyses described above were performed after stratifying participants according to 'with/without' consecutive 7-day 24-h urine collection.

\section{RESULTS}

The basic characteristics and urinary properties of the study participants are shown in Table 1 . The mean age of participants was 39.9 years. Three participants $(6.3 \%)$ were on antihypertensive medication. The mean 24-h urinary volume for 7 days was approximately 1.81 in both men and women. The mean $24-\mathrm{h} \mathrm{Na}$ excretion for 7 days was higher in men $(193.7 \mathrm{mmol}$ per $24 \mathrm{~h}$ ) than in women $(181.4 \mathrm{mmol}$ per $24 \mathrm{~h}$ ), whereas the mean 24 -h $\mathrm{K}$ excretion was similar in men ( $45.2 \mathrm{mmol}$ per $24 \mathrm{~h})$ and women $(45.5 \mathrm{mmol}$ per $24 \mathrm{~h}$ ). Casual urine Na concentration was lowest in the first morning urine specimen in both men and women. The mean $\mathrm{Na} / \mathrm{K}$ ratio of 24-h urine was 4.3 and was similar between men and women. Casual urine $\mathrm{Na} / \mathrm{K}$ ratio was the lowest for the second morning urine specimen in both sexes.

Participants were requested to collect urine for 7 consecutive days. However, 23 of 48 participants could not collect urine consecutively (15 participants needed 8 days, 5 needed 9 days, 1 needed 10 days and 2 needed 11 days to collect a total of 7-day 24-h urine collections).

Marked day-to-day variability was observed in $\mathrm{Na}$ and $\mathrm{K}$ excretion and in the $\mathrm{Na} / \mathrm{K}$ ratio of the $24-\mathrm{h}$ urine collection. Even in the participants with minimum $\mathrm{Na}$ variability in 7-day 24-h urine collection, $\mathrm{Na}$ excretion in 24 -h urine varied by $33.8 \mathrm{mmol}$ ( $28 \%$ of the 7 -day average), $\mathrm{K}$ excretion varied by $15.5 \mathrm{mmol}$ ( $47 \%$ of the $7-$ day average) and $\mathrm{Na} / \mathrm{K}$ ratio by 1.28 (35\% of the 7 -day average) during the observation period. In the participants with maximum variability, $\mathrm{Na}$ excretion in the 24-h urine samples varied by $315.4 \mathrm{mmol}$ ( $88 \%$ of the 7 -day average), $\mathrm{K}$ excretion varied by $18.5 \mathrm{mmol}$ ( $28 \%$ of the 7 -day average) and $\mathrm{Na} / \mathrm{K}$ ratio varied by 4.64 ( $86 \%$ of the 7 -day average) during the trial.

The average voiding frequency was 6.4 times per day, and the mode was 6 times per day. The random casual urine from all samples consisted of the first morning urine (19\% of all samples), the second morning urine ( $19 \%$ of all samples), the daytime casual urine ( $41 \%$ of all samples) and others ( $47 \%$ of all samples).

Correlation coefficients of casual urine $\mathrm{Na} / \mathrm{K}$ ratio with 7 -day 24 -h $\mathrm{Na} / \mathrm{K}$ ratio, $\mathrm{Na}$ excretion and $\mathrm{K}$ excretion in the 48 participants are shown in Table 2 . Correlation between casual urine $\mathrm{Na} / \mathrm{K}$ ratio and 7-day $24-\mathrm{h} \mathrm{Na} / \mathrm{K}$ ratio generally became stronger as the number of days increased. Regarding the time of casual urine collection, correlation coefficients were generally the highest for daytime casual urine: 0.85 for the mean of 3 days, 0.85 for the mean of 5 days and 0.87 for the mean of 6 and 7 days (all, $P<0.001$ ). The $\mathrm{Na} / \mathrm{K}$ ratio of random casual morning urine also strongly correlated with $24-\mathrm{h} \mathrm{Na} / \mathrm{K}$ ratio (Table 2). The correlation coefficients of the second morning urine were lower than those of the first morning urine. The mean daytime $\mathrm{Na} / \mathrm{K}$ ratio (09-17 hours) for 6-day and 7-day casual urine, and random casual urine from all urine samples, correlated most strongly with the 7 -day 24 -h urinary $\mathrm{Na} / \mathrm{K}$ ratio for individual values $(r=0.87$; Table 2 and Figure 1a).

The daytime casual urine $\mathrm{Na} / \mathrm{K}$ ratio also correlated strongly with the 7-day 24-h Na excretion $(r=0.45-0.56)$, although the correlation was less strong than its correlation with 7 -day $24-\mathrm{h} \mathrm{Na} / \mathrm{K}$ ratio (Table 2). The correlation coefficient between 7-day 24-h urine $\mathrm{Na}$ excretion and casual urine $\mathrm{Na} / \mathrm{K}$ ratio reached 0.65 for the 7 -day 
Table 1 Basic characteristics and urinary findings of study participants by gender, in 2011

\begin{tabular}{|c|c|c|c|c|c|c|}
\hline \multirow[b]{2}{*}{ Variables } & \multicolumn{2}{|c|}{ Men $(n=25)$} & \multicolumn{2}{|c|}{ Women $(n=23)$} & \multicolumn{2}{|c|}{ Total $(n=48)$} \\
\hline & Mean & s.d. & Mean & s.d. & Mean & s.d. \\
\hline Height (cm) & 174.2 & 5.0 & 156.3 & 4.6 & 165.7 & 10.2 \\
\hline Weight (kg) & 72.2 & 10.7 & 54.4 & 8.5 & 63.7 & 13.2 \\
\hline Body mass index $\left(\mathrm{kg} \mathrm{m}^{-2}\right)$ & 23.8 & 3.2 & 22.3 & 3.3 & 23.0 & 3.3 \\
\hline Alcohol consumption (g per week) & $n$ & $\%$ & $\mathrm{n}$ & $\%$ & $n$ & $\%$ \\
\hline \multicolumn{7}{|l|}{ Past history } \\
\hline Hypertension & 3 & 12.0 & 2 & 8.7 & 5 & 10.4 \\
\hline Diabetes mellitus & 1 & 4.0 & 2 & 8.7 & 3 & 6.3 \\
\hline Dyslipidemia & 5 & 20.0 & 6 & 26.1 & 11 & 22.9 \\
\hline \multicolumn{7}{|l|}{ Drug treatment } \\
\hline Dyslipidemia & 0 & 0.0 & 0 & 0.0 & 0 & 0.0 \\
\hline \multirow[t]{2}{*}{ Alcohol consumption $\geqslant 3$ days per week } & 9 & 36.0 & 3 & 13.0 & 12 & 25.0 \\
\hline & Mean & s.d. & Mean & s.d. & Mean & s.d. \\
\hline 24-h Urine volume (ml) & 1770.4 & 1095.2 & 1835.5 & 806.5 & 1801.6 & 968.2 \\
\hline 24-h Na excretion (mmol per $24 \mathrm{~h}$ ) & 193.7 & 104.5 & 181.4 & 70.9 & 187.8 & 90.2 \\
\hline 24-h K excretion (mmol per $24 \mathrm{~h}$ ) & 45.2 & 15.4 & 45.5 & 17.6 & 45.3 & 16.5 \\
\hline Urine voiding (times per day) & 6.14 & 2.57 & 6.67 & 1.95 & 6.39 & 2.31 \\
\hline \multicolumn{7}{|l|}{ Na concentration $\left(\mathrm{mmol}^{-1}\right)$} \\
\hline 24-h Urine & 118.7 & 45.5 & 108.6 & 43.8 & 113.9 & 45.0 \\
\hline \multicolumn{7}{|l|}{$K$ concentration $\left(\mathrm{mmol}^{-1}\right)$} \\
\hline 1st Morning urine & 26.2 & 12.7 & 25.1 & 12.9 & 25.7 & 12.8 \\
\hline 2nd Morning urine & 39.0 & 22.6 & 33.5 & 17.5 & 36.4 & 20.6 \\
\hline Daytime casual urine & 36.2 & 21.3 & 32.2 & 16.9 & 34.3 & 19.4 \\
\hline Random casual urine & 31.2 & 17.5 & 29.4 & 19.6 & 30.4 & 18.5 \\
\hline \multicolumn{7}{|l|}{$\mathrm{Na} / \mathrm{K}$ ratio } \\
\hline 24-h Urine & 4.48 & 2.49 & 4.25 & 1.65 & 4.37 & 2.13 \\
\hline 1st Morning urine & 4.70 & 2.58 & 4.43 & 2.49 & 4.57 & 2.54 \\
\hline 2nd Morning urine & 4.36 & 2.67 & 3.54 & 1.67 & 3.98 & 2.30 \\
\hline Daytime casual urine & 4.41 & 2.66 & 4.06 & 2.30 & 4.24 & 2.50 \\
\hline Random casual urine & 4.65 & 2.86 & 4.57 & 3.14 & 4.61 & 3.00 \\
\hline
\end{tabular}

Abbreviations: K, potassium; Na, sodium. Urinary findings are shown as means of all 7 days. Definition of daytime casual urine: urine samples collected between 0900 and 1700.

mean value with the first morning urine, 0.55 with the second morning urine, 0.56 with daytime casual urine and 0.51 with 7 -day random casual urine from all samples (Table 2).

The $\mathrm{Na} / \mathrm{K}$ ratio of daytime casual urine was most strongly correlated with $24-\mathrm{h} \mathrm{Na} / \mathrm{K}$ ratio and $\mathrm{Na}$ concentration for 7 days. Therefore, assessment of agreement for the $\mathrm{Na} / \mathrm{K}$ ratios was performed using the Bland-Altman method. Figure la shows the correlation between 7 -day 24 -h urine $\mathrm{Na} / \mathrm{K}$ ratio and the mean $\mathrm{Na}$ / $\mathrm{K}$ ratio of six daytime casual urine samples. The correlation coefficient was 0.87 , and the mean difference for the two methods was 0.03 (Figure 1b). The standard deviation of the difference between the 7-day 24-h method and the six daytime casual urine sample method was 0.92 . Therefore, the $95 \%$ of differences between the 7 -day $24-\mathrm{h}$ method and the six daytime casual urine sample method were between -1.78 and 1.84 .

The mean difference and the limits of agreement (mean \pm 2 standard deviation) between 1-, 2-, 3-day $24-\mathrm{h} \mathrm{Na} / \mathrm{K}$ ratios and the gold standard, that is, 7-day $24-\mathrm{h} \mathrm{Na} / \mathrm{K}$ ratio were compared using the 
Table 2 Correlation coefficients of casual urine $\mathrm{Na} / \mathrm{K}$ ratio with 7-day 24-h Na/K ratio, $\mathrm{Na}$ excretion and $\mathrm{K}$ excretion in 48 participants

\begin{tabular}{|c|c|c|c|c|}
\hline \multirow[b]{2}{*}{$\begin{array}{l}\text { Timing of } \\
\text { casual urine }\end{array}$} & \multirow[b]{2}{*}{$\begin{array}{c}\text { Number of } \\
\text { days to } \\
\text { calculate } \\
\text { mean }\end{array}$} & \multicolumn{3}{|c|}{ Correlation coefficients } \\
\hline & & $\begin{array}{c}24-h \\
N a / K \text { ratio }\end{array}$ & $\begin{array}{c}\text { 24-h } \mathrm{Na} \\
\text { excretion } \\
\text { (mmol per } \\
\text { 24-h) }\end{array}$ & $\begin{array}{c}\text { 24-hr K } \\
\text { excretion }^{a} \\
\text { (mmol per } \\
24-h)\end{array}$ \\
\hline \multirow[t]{7}{*}{ First morning urine } & 1 day & 0.44 & 0.31 & -0.05 \\
\hline & 2 days & 0.62 & 0.50 & -0.04 \\
\hline & 3 days & 0.67 & 0.58 & -0.04 \\
\hline & 4 days & 0.65 & 0.56 & -0.05 \\
\hline & 5 days & 0.67 & 0.59 & -0.04 \\
\hline & 6 days & 0.68 & 0.64 & 0.01 \\
\hline & 7 days & 0.69 & 0.65 & 0.03 \\
\hline \multirow[t]{7}{*}{ Second morning urine } & 1 day & 0.57 & 0.24 & -0.31 \\
\hline & 2 days & 0.74 & 0.44 & -0.27 \\
\hline & 3 days & 0.76 & 0.52 & -0.23 \\
\hline & 4 days & 0.76 & 0.50 & -0.26 \\
\hline & 5 days & 0.75 & 0.48 & -0.27 \\
\hline & 6 days & 0.78 & 0.55 & -0.22 \\
\hline & 7 days & 0.78 & 0.55 & -0.22 \\
\hline Daytime casual urine & 1 day & 0.68 & 0.45 & -0.16 \\
\hline \multirow[t]{6}{*}{ (09-17 hours) } & 2 days & 0.79 & 0.53 & -0.19 \\
\hline & 3 days & 0.85 & 0.56 & -0.22 \\
\hline & 4 days & 0.84 & 0.56 & -0.21 \\
\hline & 5 days & 0.85 & 0.56 & -0.24 \\
\hline & 6 days & 0.87 & 0.55 & -0.26 \\
\hline & 7 days & 0.87 & 0.56 & -0.24 \\
\hline Random casual urine & 1 day & 0.51 & 0.28 & -0.18 \\
\hline \multirow[t]{6}{*}{ (selected from each day) } & 2 days & 0.64 & 0.37 & -0.16 \\
\hline & 3 days & 0.71 & 0.38 & -0.25 \\
\hline & 4 days & 0.82 & 0.48 & -0.26 \\
\hline & 5 days & 0.85 & 0.51 & -0.27 \\
\hline & 6 days & 0.87 & 0.54 & -0.26 \\
\hline & 7 days & 0.87 & 0.51 & -0.28 \\
\hline
\end{tabular}

Abbreviations: K, potassium; Na, sodium.

aMean values of all 7 days.

Bland and Altman agreement method. The 'agreement' of 6-day daytime casual urine $\mathrm{Na} / \mathrm{K}$ ratio was better than 1-day 24 -h urine $\mathrm{Na}$ / $\mathrm{K}$ ratio (mean difference: 0.17 ; $95 \%$ of differences: -2.10 to 2.44 ) and almost similar to the agreement of the 2 -day 24 -h urine $\mathrm{Na} / \mathrm{K}$ ratio $(r=0.88$; mean difference: 0.29 and $95 \%$ of differences: -1.44 to 2.01; Figures $2 \mathrm{a}$ and $\mathrm{b}$ ).

Although the correlation coefficients of random casual urine were similar to those of daytime casual urine, as shown in Table 2, the agreement calculated by Bland-Altman analyses was not as strong as that in daytime casual urine samples (bias of daytime casual urine: between -0.03 and 0.06 for 5 and 7 days, bias of random casual urine: between -0.31 and -0.44 for 5 and 7 days). Biases of daytime casual urine were generally small; however, those of 1 day to 5 days were larger than those of 6 and 7 days (between -0.03 and -0.41 for 1 day to 5 days, 0.03 and 0.06 for 6 and 7 days, respectively).

Table 3 shows the correlation coefficients for casual urine $\mathrm{Na}$ concentration with 7 -day $24-\mathrm{h} \mathrm{Na} / \mathrm{K}$ ratio, $\mathrm{Na}$ excretion and $\mathrm{K}$ excretion in all of the 48 participants. Correlation coefficients of casual urine $\mathrm{Na}$ concentration with all three parameters in 7-day 24-h urine were not as high as those with $\mathrm{Na} / \mathrm{K}$ ratio, as shown in Table 2; a
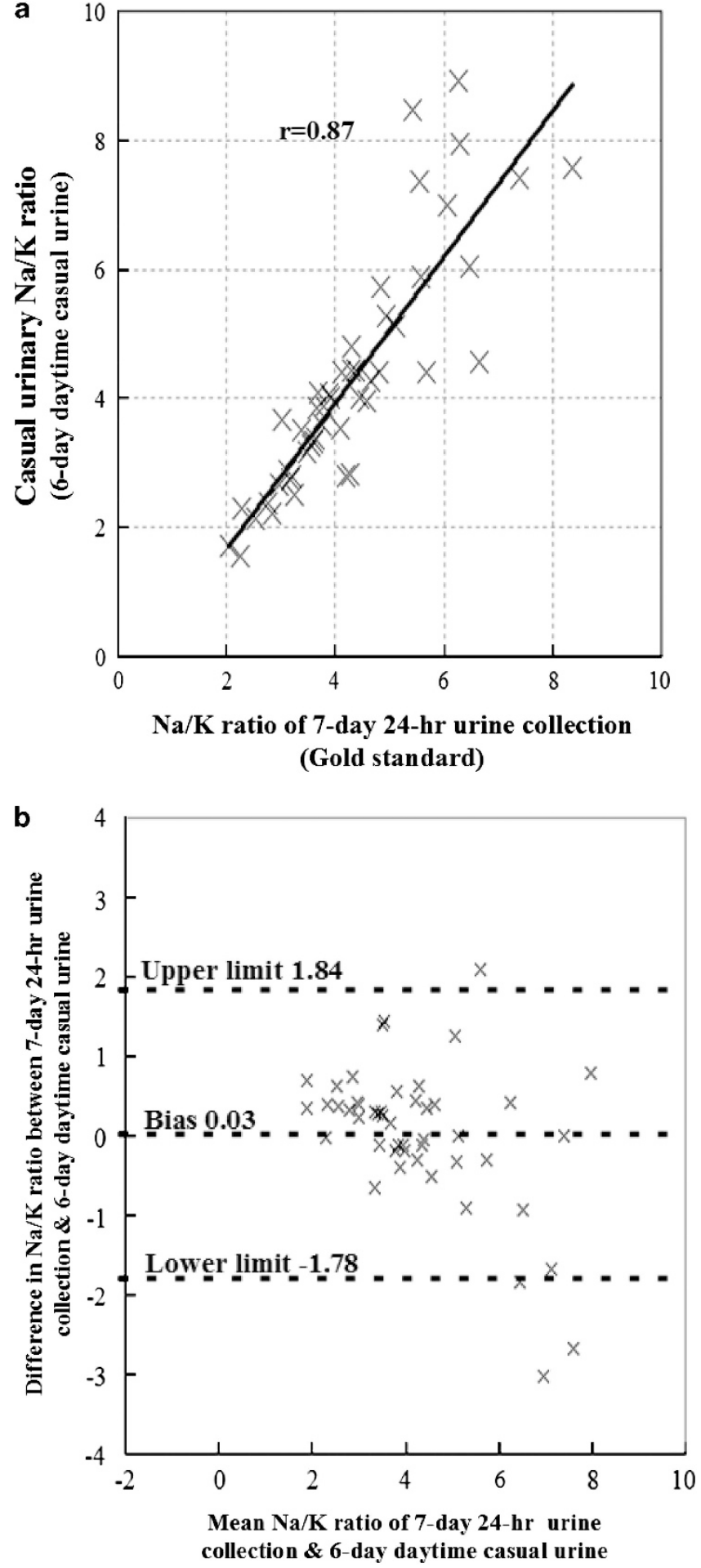

Figure 1 (a and b) Pearson's correlation coefficient between 7-day 24-h urine $\mathrm{Na} / \mathrm{K}$ ratio and 6-day daytime (09-17 hours) casual urine $\mathrm{Na} / \mathrm{K}$ ratio (the new method) for the 48 participants was 0.87 (a). The bias between 7-day 24-h Na/K ratio and the 6-day daytime casual urine $\mathrm{Na} / \mathrm{K}$ ratio by Bland-Altman analysis ${ }^{21}$ was -0.03 , with $95 \%$ of differences between -1.78 and 1.84 (b). The quality of agreement by Bland-Altman analysis ${ }^{21}$ was similar to that shown in Figures $2 a$ and $b$, which shows Pearson's correlation coefficient and the bias with 95\% of differences between 2-day 24-h urine $\mathrm{Na} / \mathrm{K}$ ratio and 7-day 24-h urine $\mathrm{Na} / \mathrm{K}$ ratio. 

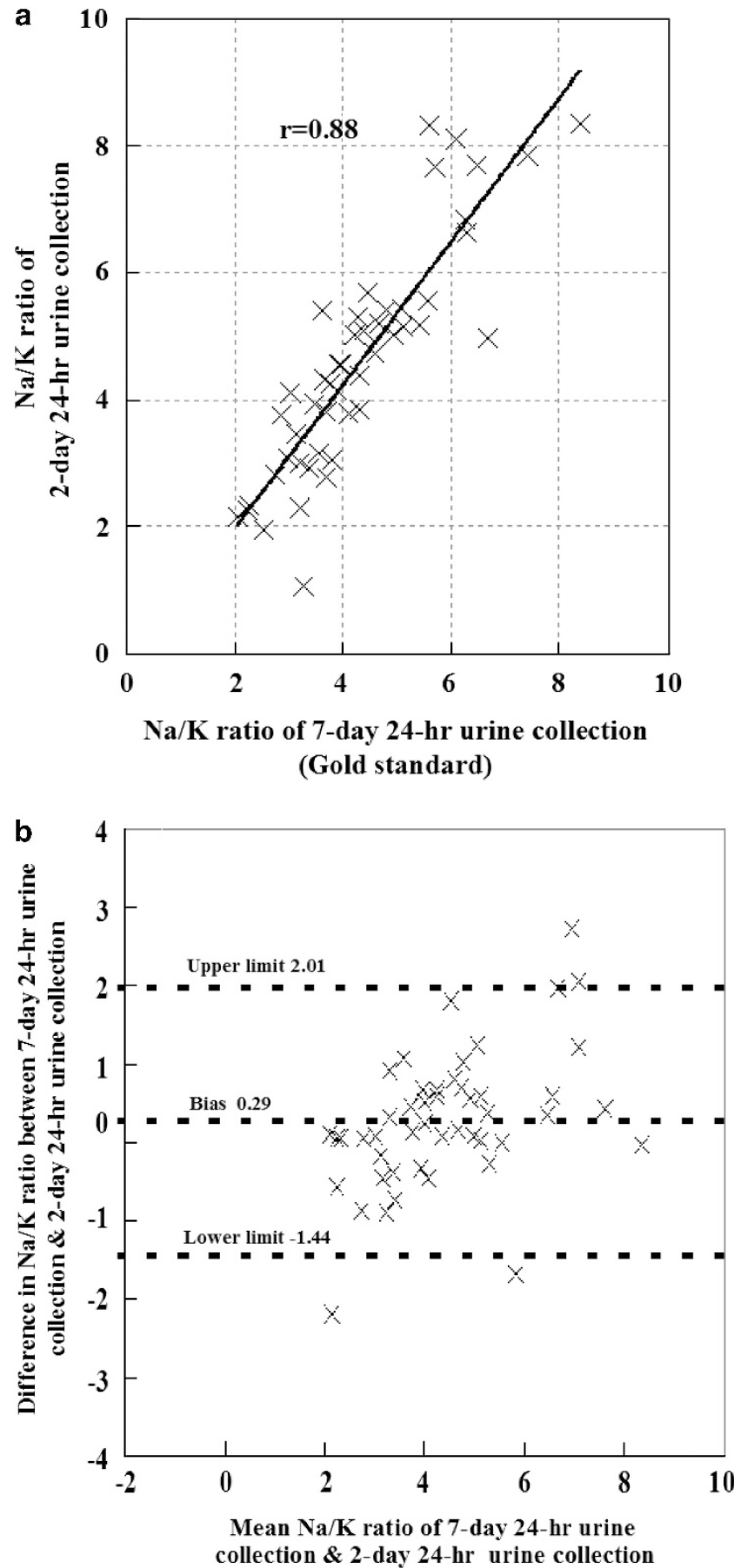

Figure 2 ( $\mathbf{a}$ and $\mathbf{b}$ ) Pearson's correlation coefficient between 7-day 24-h Na/ $\mathrm{K}$ ratio and 2-day $24-\mathrm{h} \mathrm{Na} / \mathrm{K}$ ratio for the 48 participants was 0.88 (a). The bias between 2-day 24-h urine $\mathrm{Na} / \mathrm{K}$ ratio and 7-day 24-h urine $\mathrm{Na} / \mathrm{K}$ ratio by Bland-Altman analysis ${ }^{21}$ was 0.29 , with $95 \%$ of differences between -1.44 and 2.01 (b).

correlation coefficients were between 0.05 and 0.14 for daytime casual urine and 24-h $\mathrm{Na}$ excretion.

The stratified analyses comparing consecutive and non-consecutive 24-h urine collection samples showed similar results with respect to the correlation coefficients and agreements for six daytime random casual urine $\mathrm{Na} / \mathrm{K}$ ratio and 7 -day $24-\mathrm{h} \mathrm{Na} / \mathrm{K}$ ratio (correlation:
Table 3 Correlation coefficients of casual urine $\mathrm{Na}$ concentration with 7-day 24-h Na/K ratio, $\mathrm{Na}$ excretion and $\mathrm{K}$ excretion in 48 participants

\begin{tabular}{|c|c|c|c|c|}
\hline \multirow[b]{2}{*}{$\begin{array}{l}\text { Time of casual } \\
\text { urine }\end{array}$} & \multirow[b]{2}{*}{$\begin{array}{c}\text { Number of } \\
\text { days to } \\
\text { calculate } \\
\text { mean }\end{array}$} & \multicolumn{3}{|c|}{ Correlation coefficients } \\
\hline & & $\begin{array}{l}24-h \\
\mathrm{Na} / \mathrm{K} \\
\text { ratio }\end{array}$ & $\begin{array}{l}\text { 24-h } \mathrm{Na} \\
\text { excretion }{ }^{\mathrm{a}} \\
(\mathrm{mmol} p e r \\
24 h)\end{array}$ & $\begin{array}{c}24-h K \\
\text { excretion }^{\text {a }} \\
\text { (mmol per } \\
24 h)\end{array}$ \\
\hline \multirow[t]{7}{*}{ First morning urine } & 1 day & 0.21 & 0.11 & -0.05 \\
\hline & 2 days & 0.32 & 0.29 & 0.09 \\
\hline & 3 days & 0.35 & 0.36 & 0.11 \\
\hline & 4 days & 0.36 & 0.33 & 0.06 \\
\hline & 5 days & 0.39 & 0.34 & 0.04 \\
\hline & 6 days & 0.40 & 0.36 & 0.05 \\
\hline & 7 days & 0.39 & 0.35 & 0.05 \\
\hline \multirow[t]{7}{*}{ Second morning urine } & 1 day & 0.34 & -0.01 & -0.34 \\
\hline & 2 days & 0.35 & 0.12 & -0.22 \\
\hline & 3 days & 0.36 & 0.15 & -0.22 \\
\hline & 4 days & 0.33 & 0.13 & -0.23 \\
\hline & 5 days & 0.35 & 0.15 & -0.21 \\
\hline & 6 days & 0.36 & 0.20 & -0.17 \\
\hline & 7 days & 0.35 & 0.17 & -0.18 \\
\hline Daytime casual urine & 1 day & 0.33 & 0.05 & -0.27 \\
\hline \multirow[t]{6}{*}{ (09-17 hours) } & 2 days & 0.38 & 0.12 & -0.24 \\
\hline & 3 days & 0.37 & 0.07 & -0.29 \\
\hline & 4 days & 0.39 & 0.11 & -0.28 \\
\hline & 5 days & 0.43 & 0.14 & -0.29 \\
\hline & 6 days & 0.41 & 0.13 & -0.29 \\
\hline & 7 days & 0.43 & 0.13 & -0.29 \\
\hline Random casual urine & 1 day & 0.36 & 0.23 & -0.06 \\
\hline \multirow[t]{6}{*}{ (selected from each day) } & 2 days & 0.31 & 0.23 & 0.01 \\
\hline & 3 days & 0.37 & 0.20 & -0.09 \\
\hline & 4 days & 0.45 & 0.21 & -0.18 \\
\hline & 5 days & 0.49 & 0.22 & -0.22 \\
\hline & 6 days & 0.47 & 0.24 & -0.19 \\
\hline & 7 days & 0.47 & 0.23 & -0.18 \\
\hline
\end{tabular}

Abbreviations: K, potassium; Na, sodium.

a Means of all 7 days.

0.81 vs. 0.90 for consecutive and non-consecutive participants; bias: -0.02 vs. 0.07 , respectively).

\section{DISCUSSION}

We found that six random daytime (09-17 hours) casual urine specimens on different days are suitable to estimate the individual daily $\mathrm{Na} / \mathrm{K}$ ratio determined by 7 -day consecutive 24 -h urine collections. Pearson's correlation coefficient between both methods was 0.87 for the $\mathrm{Na} / \mathrm{K}$ ratio. The bias, defined by Bland-Altman analysis, between the 7 -day $24-\mathrm{h} \mathrm{Na} / \mathrm{K}$ ratio as the gold standard and the 6-day daytime casual urine $\mathrm{Na} / \mathrm{K}$ ratio was almost negligible (bias $=0.03$ ).

These findings suggest that this method, which uses six random daytime urine $\mathrm{Na} / \mathrm{K}$ ratio calculations, can be applied as a convenient tool to support patients and the general population in their efforts to reduce dietary salt and increase potassium intake in daily life. From the INTERSALT ${ }^{13}$ and other studies, ${ }^{14-17}$ it is well known that the $\mathrm{Na} / \mathrm{K}$ ratio in 24 -h urine is related to blood pressure. Therefore, it is reasonable and practical for patients and the general population to 
use the $\mathrm{Na} / \mathrm{K}$ ratio to monitor their daily salt and potassium intake and to achieve blood pressure control.

Typically, repeated 24-h urine collections are needed to estimate an individual's daily $\mathrm{Na} / \mathrm{K}$ ratio and sodium intake. ${ }^{7}$ However, assessment of the $\mathrm{Na} / \mathrm{K}$ ratio in six random daytime casual urine specimens on different days, rather than sodium intake itself, as a monitoring index for dietary improvement, would be easier and more practical for patients in outpatient clinics and at home. Use of daytime casual urine imposes a far lower patient burden than 24-h urine collection. Moreover, the cost is lower compared with that of repeated 24-h urine collection. This method may become a useful tool for self-monitoring of daily salt intake and/or $\mathrm{Na} / \mathrm{K}$ ratio in hypertensive patients, although the effect of this method on dietary changes warrants a clinical trial.

This study included the consecutive 7-day 24-h urine collection data as the standard for daily dietary $\mathrm{Na} / \mathrm{K}$ ratio and sodium intake in 48 middle-aged men and women. Based on the INTERSALT study in Japan, Tanaka et al. ${ }^{19}$ reported that a one-spot urine sample can be used for estimating 24-h urine sodium excretion, as a 'population' average of salt intake. However, the number of casual urine samples needed to estimate individual salt excretion and $\mathrm{Na} / \mathrm{K}$ ratio was unknown. Therefore, the present study provides important information that may be applicable to a large-scale epidemiologic study on the relationship between $\mathrm{Na} / \mathrm{K}$ ratio, $\mathrm{Na}$ and health issues.

The adequacy of six daytime casual urine samples in estimating the $\mathrm{Na} / \mathrm{K}$ ratio of 7-day 24 -h urine collection may be related to the mean frequency of daily urine voiding among participants. The average voiding frequency among participants was 6.4 times per day. In addition, the $\mathrm{Na} / \mathrm{K}$ ratio of the first morning urine did not show a strong correlation with that of 7-day 24-h urine. Therefore, six daytime random urine specimens collected over 7 days may be equivalent to 1- or 2-day 24-h urine collection in participants.

$\mathrm{The} \mathrm{Na} / \mathrm{K}$ ratio and $\mathrm{Na}$ concentration in the first morning urine were lower than the mean values in 7-day 24-h urine collections. This diurnal variation in $\mathrm{Na}$ excretion as explained by Kawasaki's equation ${ }^{18}$ suggests that the second voiding of casual urine may be suitable for the estimation of daily sodium excretion. The second morning urine, daytime casual urine (09-17 hours) and urine collected before bedtime (data not shown) appeared to have higher $\mathrm{Na}$ concentrations and lower $\mathrm{Na} / \mathrm{K}$ ratio in comparison to 24 -h urine. However, both $\mathrm{Na}$ and $\mathrm{K}$ concentrations were relatively lower in first morning urine, resulting in lower $\mathrm{Na}$ concentration and higher $\mathrm{Na} / \mathrm{K}$ ratio in comparison to 24 -h urine. As $60 \%$ and $72 \%$ of the second morning urine were collected between 08 hours and noon in men and women, respectively (data not shown), the tendency for higher $\mathrm{Na}$ concentration with lower $\mathrm{Na} / \mathrm{K}$ ratio compared with 24 -h urine may partly be an effect of eating breakfast.

The method used here for evaluation of $\mathrm{Na}, \mathrm{K}$ excretion and $\mathrm{Na} / \mathrm{K}$ ratio in 24-h urine collection was not a single measurement; instead, it consisted of weighted summation of each casual urine voiding. In addition, urine was analyzed using ion-selective electrodes. However, the values of $\mathrm{Na}$ and $\mathrm{K}$ excretion and $\mathrm{Na} / \mathrm{K}$ ratio obtained in the present study were almost the same as those observed in Japanese participants from the INTERSALT study in 1983 (that is, $\mathrm{Na} / \mathrm{K}$ ratios in men and women aged 20-59 years were between 4.2-4.6 and 4.0-4.6, respectively) and the INTERMAP study in 1996 (that is, $\mathrm{Na} / \mathrm{K}$ ratios in men and women aged 40-59 years were 4.5 and 4.1, respectively). ${ }^{7,22}$ Therefore, this finding suggests that the methods used in the present study are acceptable compared with the standard method of 24-h urine collection used in the INTERSALT and INTERMAP studies.
Currently, there is no clear recommended cutoff value for an acceptable $\mathrm{Na} / \mathrm{K}$ ratio. The World Health Organization guidelines recommend adjusting one's lifestyle to achieve a $\mathrm{Na} / \mathrm{K}$ ratio of less than $1 .^{12}$ According to the INTERSALT study, ${ }^{22}$ the $\mathrm{Na} / \mathrm{K}$ ratio ranged from 0.01 (observed in Yanomamo, Brazil: with $0.9 \mathrm{mmol} \mathrm{Na}$ per $24 \mathrm{~h}$ ) to 7.31 (observed in Tianjin, China: with $245.6 \mathrm{mmol} \mathrm{Na}$ per $24 \mathrm{~h}$ ) in different populations. Three Japanese cohorts demonstrated a $\mathrm{Na} / \mathrm{K}$ ratio of approximately 3.90 to 4.64 with a $\mathrm{Na}$ per $24 \mathrm{~h}$ of 145 to $224 \mathrm{mmol}$. Using Chicago as being representative of a Western population with low salt consumption, the $\mathrm{Na} / \mathrm{K}$ ratio was 2.62 when urinary sodium excretion was $140.0 \mathrm{mmol}$. Therefore, the target value for $\mathrm{Na} / \mathrm{K}$ ratio in Japanese may be less than 3, considering the present sodium excretion and urinary $\mathrm{Na} / \mathrm{K}$ ratio in this population.

We found no major differences in the estimation of the $\mathrm{Na} / \mathrm{K}$ ratio in urine collections of 7 consecutive days compared with that of 7 non-consecutive days. Thus, we believe that consecutive-day urine collections are not necessary for adequate $\mathrm{Na} / \mathrm{K}$ estimation. In this study, we assessed the ability of six random urine samples to adequately estimate daily $\mathrm{Na} / \mathrm{K}$ ratio. We selected casual urine randomly from among the 7 days of collection, with only one sample being collected per day. Therefore, we can assume that six random casual urine samples collected over the observation period are important in estimating $\mathrm{Na} / \mathrm{K}$ ratio during the given observation period.

A limitation of this study is that the participants were middle-aged men and women, and only $6 \%$ of the participants were on antihypertensive medications. It is not known whether the findings are also applicable to the elderly and patients receiving antihypertensive medication.

In conclusion, the method of estimation of daily urinary $\mathrm{Na} / \mathrm{K}$ ratio and urinary sodium excretion using six random specimens of daytime (09-17 hours) casual urine on different days is a good substitute for 2-day 24-h urine collection, as observed in this study. This method may become a convenient tool to help patients reduce their daily salt intake and increase their potassium intake, thus lowering their blood pressure. This method may also be applicable to cohort studies for estimating individual daily urinary $\mathrm{Na} / \mathrm{K}$ ratio as a substitute for 2-day 24-h urine collection.

\section{ACKNOWLEDGEMENTS}

This study was conducted by OMRON HEALTHCARE Co. Ltd. in cooperation with the Department of Health Science, Shiga University of Medical Science. The running cost of this observational study was obtained from a budget from OMRON HEALTHCARE Co. Ltd. Dr Hirotsugu Ueshima served as a consultant for this project. Dr Katsuyuki Miura received research funding from OMRON HEALTHCARE Co. Ltd.

1 He FJ, MacGregor GA. A comprehensive review on salt and health and current experience of worldwide salt reduction programmes. J Hum Hypertens 2009; 23 363-384

2 Ogihara T, Kikuchi K, Matsuoka H, Fujita T, Higaki J, Horiuchi M, Imai Y, Imaizumi T, Ito S, Iwao H, Kario K, Kawano Y, Kim-Mitsuyama S, Kimura G, Matsubara H, Matsuura $\mathrm{H}$, Naruse M, Saito I, Shimada K, Shimamoto K, Suzuki H, Takishita S, Tanahashi N, Tsuchihashi T, Uchiyama M, Ueda S, Ueshima H, Umemura S, Ishimitsu T, Rakugi H, Japanese Society of Hypertension Committee. The Japanese society of hypertension guidelines for the management of hypertension (JSH 2009). Hypertens Res 2009; 32: 3-107.

3 Chobanian AV, Bakris GL, Black HR, Cushman WC, Green LA, Izzo JL Jr, Jones DW, Materson BJ, Oparil S, Wright JT Jr, Roccella EJ, Joint National Committee on Prevention, Detection, Evaluation, and Treatment of High Blood Pressure. National Heart, Lung, and Blood Institute; National High Blood Pressure Education Program 
Coordinating Committee. Seventh report of the Joint National Committee on Prevention, Detection, Evaluation, and Treatment of High Blood Pressure. Hypertension 2003; 42: 1206-1252.

4 Ramsay L, Williams B, Johnston G, MacGregor G, Poston L, Potter J, Poulter N, Russell G. Guidelines for management of hypertension: report of the third working party of the British Hypertension Society. J Hum Hypertens 1999; 13: 569-592.

5 Whitworth JA World Health Organization/International Society of Hypertension Writing Group. 2003 World Health Organization (WHO)/International Society of Hypertension (ISH) statement on management of hypertension. J Hypertens 2003; 21: 1983-1992.

6 Stamler J, Elliott P, Dennis B, Dyer AR, Kesteloot H, Liu K, Ueshima H, Zhou BF, The INTERMAP Research Group. INTERMAP: background, aims, design, methods, and descriptive statistics (nondietary). J Hum Hypertens 2003; 17: 591-608.

7 INTERSALT Cooperative Research Group. INTERSALT: an international study of electrolyte excretion and blood pressure. Results for 24-hr urinary sodium and potassium excretion. BMJ 1988; 297: 319-328.

8 Rose G, Stamler J, INTERSALT co-operative Research Group. The INTERSALT study: background, methods and main results. J Hum Hypertens 1989; 3: 283-288.

9 Taylor EN, Stampfer MJ, Mount DB, Curhan GC. DASH-style diet and 24-hr urine composition. Clin J Am Soc Nephrol 2010; 5: 2315-2322.

10 Kesteloot H, Tzoulaki I, Brown IJ, Chan Q, Wijeyesekera A, Ueshima H, Zhao L, Dyer AR, Unwin RJ, Stamler J, Elliott P. Relation of urinary calcium and magnesium excretion to blood pressure. The International Study of Macro- And Micro-nutrients And Blood Pressure and The International Cooperative Study on Salt, Other Factros, and Blood Pressure. Am J Epidemiol 2011; 174: 44-51.

11 Dennis B, Stamler J, Buzzard M, Conway R, Elliott P, Moag-Stahlberg A, Okayama A, Okuda N, Robertson C, Robinson F, Schakel S, Stevens M, Van Heel N, Zhao L, Zhou BF, INTERMAP Research Group. INTERMAP:the dietary data-process and quality control. J Hum Hypertens 2003; 17: 609-622.

12 WHO Guideline Potassium Intake for Adults and Children World Health Organization (WHO), Geneva, 2012.
13 Stamler J, Rose G, Stamler R, Elliott P, Dyer A, Marmot M. INTERSALT study findings. Public health and medical care implications. Hypertension 1989; 14: 570-577.

14 Chien KL, Hsu HC, Chen PC, Su TC, Chang WT, Chen MF, Lee YT. Urinary sodium and potassium excretion and risk of hypertension in Chinese: report from a communitybased cohort study in Taiwan. J Hypertens 2008; 26: 1750-1756.

15 Cook NR, Obarzanek E, Cutler JA, Buring JE, Rexrode KM, Kumanyika SK, Appel LJ, Whelton PK Trials of Hypertension Prevention Collaborative Research Group. Joint effects of sodium and potassium intake on subsequent cardiovascular disease: the Trials of Hypertension Prevention follow-up study. Arch Intern Med 2009; 169: 32-40.

16 Huggins CE, O'Reilly S, Brinkman M, Hodge A, Giles GG, English DR, Nowson CA. Relationship of urinary sodium and sodium-to-potassium ration to blood pressure in older adults in Australia. Med J Aust 2011; 195: 128-132.

17 Hedayati SS, Minhajuddin AT, Ijaz A, Moe OW, Elsayed EF, Reilly RF, Huang CL. Association of urinary sodium/potassium ratio with blood pressure: sex and racial differences. Clin J Am Soc Nephrol 2012; 7: 315-322.

18 Kawasaki T, Ueno M, Uezono K, Kawazoe N, Nakamuta S, Ueda K, Omae T. Average urinary excretion of sodium in 24 hours can be estimated from a spot-urine specimen. Jpn Circ J 1982; 46: 948-953.

19 Tanaka T, Okamura T, Miura K, Kadowaki T, Ueshima H, Nakagawa H, Hashimoto T. A simple method to estimate populational 24-h urinary sodium and potassium excretion using a casual urine specimen. J Hum Hypertens 2002; 16: 97-103.

20 Brown IJ, Dyer AR, Chan Q, Cogswell ME, Ueshima H, Stamler J, Elliott P, the INTERMAP Co-Operative Research Group. Estimating 24-hr urinary excretion from casual urinary sodium concentrations in western populations: the INTERSALT study. Am J Epidemiol 2013; 177: 1180-1192.

21 Bland J, Altman DG. Statistical methods for assessing agreement between two methods of clinical measurement. Lancet 1986; 1: 307-310.

22 Stamler J, Elliott P, Chan Q, the INTERMAP Research Group. INTERMA appendix tables. J Hum Hypertens 2003; 17: 665-775. 